\title{
THE USE OF HYPSOMETRY TO INDICATE LONG-TERM STABILITY AND RESPONSE OF VALLEY GLACIERS TO CHANGES IN MASS TRANSFER
}

\author{
By D. J. Furbish and J. T. Andrews
}

(Department of Geological Sciences and Institute of Arctic and Alpine Research, University of Colorado, Boulder, Colorado 80309, U.S.A.)

Abstract. A simple equation is derived relating the net mass-balance and hypsometric curves of a steady-state valley glacier. It is used to examine how valley shape is linked to disparate extents and responses of glaciers subjected to similar climatic conditions. Examples are given which show that area-based indices (e.g. AAR) for estimating the equilibrium line altitude $(E L \Lambda)$ may be subject to a substantial built-in variance because they implicitly rely upon similarity of glacier shape and regimen over a region. If accurate topographic maps are available, the equation may be used to infer the regimen of modern glaciers in the form of a dimensionless ratio of net mass-balance gradients. Alternatively, if similar information is available concerning regional glacier regimen, disparate extents and responses may be collectively utilized to estimate values of E.LA or to infer climatic influence, taking glacier hypsometry into account.

Résumé. De l'utilisation de l'hypsomélrie comme indicateur de stabilité à long terme et des réponses des glaciers de vallée à des changements dans les bilans de masse. Une équation simple est obtenue reliant la courbe de bilan de masse net et la courbe hypsométrique d'un glacier de vallée en équilibre. Elle est utilisée pour examiner comment la forme de la vallée est liée à des extensions et des réponses contrastées de glaciers soumis à des conditions climatiques semblables. Des exemples sont donnés qui montrent que des indices basés sur les surfaces (par exemple l'AAR.) pour l'estimation de l'élévation de la ligne d'équilibre (ELA) peuvent être sujets à une variance incorporée substan tielle parce qu'elle repose implicitement sur une similitude de la forme et du régime des glaciers sur toute une région. Si l'on dispose de cartes topographiques précises l'équation peut être utilisée pour retrouver le régime des

\section{INTRODUCTION}

The disparate ways in which valley glaciers respond to changes in climate has long attracted the attention of Quaternary scientists. Disparate responses confuse any attempt to generalize in a simple way how glaciers of a region should, or have, responded to climatic events. Some variation can be explained by differences in local climate surrounding individual glaciers, but much variation must be explained by the many morphologic and glaciological features which distinguish individual glaciers, including differences in size, steepness, elevation, mass turnover, areal distribution of accumulation and ablation, etc. (Andrews and others, 1970; Paterson, 1981). (Many of these features, in fact, are linked with local climate.)

Much effort has been devoted to understanding the many linkages between glaciers, their morphology, and the surrounding $\mathrm{climate}$. An understanding of these linkages forms the base for the particular problem of climatic reconstruction. This problem requires detailing the mechanisms of adjustment between input (climate) and output (glacier geometry) from which the inverse may be deduced - whether it concerns changes over an historical record (Nye, 1965; Kuhn, [1981]; Smith and Budd, [1981]), or changes inferred from the glacial geologic record (Meier, 1965; Andrews, [C1975]). However, because of the number and complexity of linkages, frequently only certain ones can be accounted for in explaining or predicting glacier response whereas the majority contribute, to greater or less degrees, to unexplained variance in the predictions. This is particularly bothersome as the record of changes in glacier regimen becomes more incomplete with increasingly older glacial events. This is sufficient reason to continue to examine our glaciers modernes sous la forme d'un rapport adimensionnel entre les gradients de bilan de masse. Réciproquement si de semblables informations existent sur le régime des glaciers de la région, les différences des extensions et des réponses peuvent être utilisées ensembles pour estimer l'ELA ou pour reconstituer l'influence climatique en prenant en compte l'hypsométrie du glacier

Zusammenfassung. Benulzung der Höhengestall zur Kennzeichnung der Langzeit-Stabilität und der Reaktion von Talgletschern auf Änderungen im Massentransport. Mit Hilfe einer Beziehung zwischen dem NettoMassenbilanzbild und dem Höhenlinienbild eines Talgletschers wird eine einfache Gleichung für dessen stationären Zustand hergeleitet. Diese wird benutzt, um zu untersuchen, wie die Talform mit verschiedenen Ausmassen und Reaktionen von Gletschern, die ähnlichen klimatischen Bedingungen unterliegen, verbunden ist. Es werden Beispiele vorgeführt, die zeigen, dass gebietsabhängige Indizes (z.B. AAR) zur Abschätzung der Höhe der Gleichgewichtslinie (ELA) eine wesentliche innere Schwankungsbreite besitzen können, weil sie implizit eine Ahnlichkeit der Gletscherform und des Haushalts innerhalb eines Gebietes voraussetzen. Sind genaue topographische Karten vorhanden, so kann die Gleichung dazu benutzt werden, den Haushalt junger Gletscher in Form eines dimensionslosen Verhältnisses von Gradienten der Netto-Massenbilanz abzuleiten. Sind ähnliche Informationen über den regionalen Gletscherhaushalt verfügbar, so können ersatzweise verschiedene Ausmasse und Reaktionen kollektiv zur Abschätzung der ELA oder zur Ableitung des klimatischen Einflusses unter Berücksichtigung der Höhengestalt des Gletschers herangezogen werden.

understanding of the many linkages between glacier response and climate in an effort to "isolate" causes of variation and thereby take them into account. And it is particularly worthwhile because so much of our understanding of past climates is based on interpretations of the glacial geological record.

Our objective in this paper is to consider a smal part of the problem, namely to examine one way in which valley topography is linked to long-term glacier response through the distribution of a glacier's surface area over elevation and the distribution of mass balance over elevation. We will show that area-based indices (e.g. AAR, the accumulation area ratio) for estimating values of ELA (equilibrium line altitudes) may be subject to a substantial built-in variance because they rely upon similarity of glacier shape and regimen over a region.

The classic flow diagram of Meier (1965) linking regional climate ultimately with the geologic record (Fig. 1) serves well as a conceptual framework in which the effects of topography may be considered. Figure 1 is divided to correspond with what Meier and Tangborn (1965) point out to be two parts of the problem of relating glacier response to climate. The first (Fig. la) concerns treatment of a glacier as a dynamic boundary over which mass and energy are exchanged with the atmosphere to produce temporal and spatial variations in the mass balance of the glacier (Kuhn, [1981]). Topography is linked to regional climate within this boundary system to produce local variations in mass input ( 1 ink 1) and energy balance (link 2). Link 1 includes such factors as orographic effects on snow accumulation, snow drifting due to local wind patterns, and susceptibility of valley walls to avalanching. Link 2 chiefly concerns local variations of insolation with aspect, its modification through topographic shading, or the effects of 


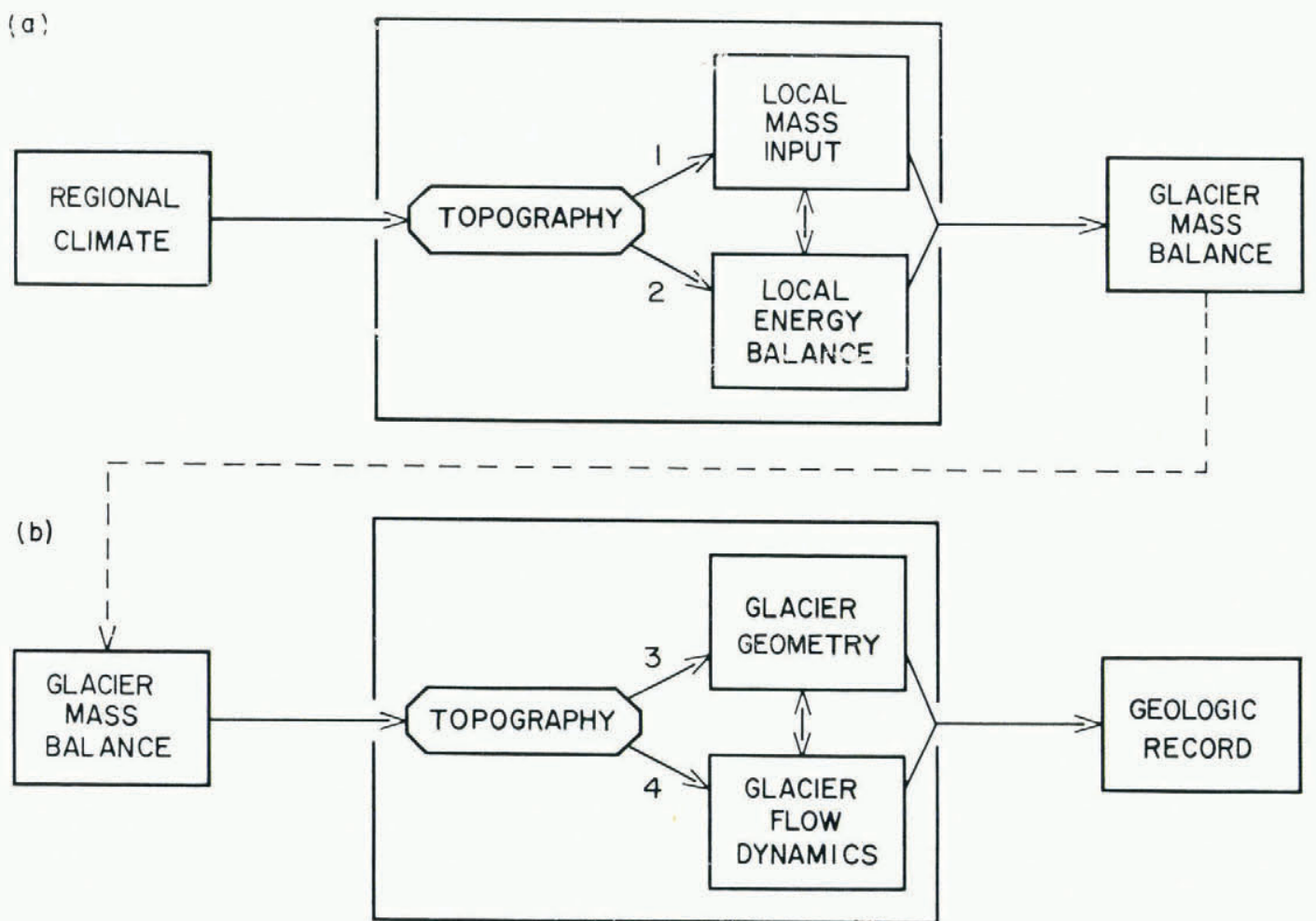

Fig. 1. (a) Generalized linkage between regional climate and individual glacier mass balance; topography modifies this linkage by affecting local climate, i.e. local mass input and energy balance. (b) Linkage between mass balance and glacier response as reflected by the geologic record; topography limits, in part, glacier geometry and affects ice-flow dynamics. See text for explanation of links $1-4$. (Figure modified from Meier (1965) and Andrews ([ $\left.\left.{ }_{1} 1975\right].\right)$

local wind patterns on sensible heat transfers. The scales over which these links operate correspond to the domain of boundary-layer climate features (Oke, 1978). Additionally, though not shown, there are more-or-less direct linkages between climate and flow dynamics in Figure 1b. Examples include the effects of available thermal energy on ice temperature and the availability of water for delivery to the base of the ice (Paterson, 1981).

The second part of the problem of relating glacier response to climate concerns treatment of the dynamics of the ice body which lead to variations in glacier geometry (Fig. 1b). Topography is linked to this system as a boundary which physically restricts the dimensions of the ice, its areal distribution over elevation, and hence, elevational variations in mass balance (link 3 ); and which interacts with the base of the ice, locally affecting such factors as flow patterns, flow rates, surface gradient, and ice thickness (link 4). As suggested by the double (feedback) arrow, these factors in the flow diagram are interactive, and this has important consequences to be discussed later. Link 3 , between mass balance and geometry, is the chief concern of this paper.

\section{LONG-TERM RESPONSE AND STATIONARITY}

It is usually the case that the output of the first aspect of the problem, i.e. mass balance, is taken as input for the treatment of the ice dynamics (e.g. Nye, 1965; Budd and Jenssen, [1975]; Allison and Kruss, 1977). Similarly, in the following treatment of the relation between topography and glacier response, we largely neglect links 1 and 2, and treat changes in climate as equivalent to changes in accumulation and ablation. For simplicity, particularly with respect to long-term response, we will consider them to be step changes between stationary conditions.

This must include the understanding that a particular balance curve (expressed in relation to elevation) may not become "set" until transition between stationary states is complete. This is because the response of a glacier to an implied step change in surface mass flux may not consist of a simple advance or retreat. A change in mass flux may lead to adjustments in local ice thickness, surface gradient, flow rate, and basal shear stresses which, through feedback, may influence the local surface mass flux. Therefore, the change in a mass-balance curve ("input") associated with a change in climate reflects not only the linkages with regional climate depicted in Figure la, but also the local mutual adjustments between geometry ("output") and flow dynamics depicted in Figure $1 b$.

The assumption of "step changes between stationary conditions" is necessary to treat long-term response inferred from old glacial deposits. However, longterm stationarity includes random fluctuations about the average mass-balance conditions and average geometry (inferred from the geologic record) that we are attempting to correlate. In this respect, moraine positions, upon which valley-glacier reconstructions are most frequently based, reflect the sum of transient depositional events. The spatial average of the terminus position, presumed to be closely mimicked by the terminal moraine, may not correspond to the timeaveraged mass-balance conditions. Therefore, to use the stationarity assumption, it is necessary to assert that fluctuations in the terminus are restricted to a small percentage of the total glacier extent, and that large moraines constructed over tens or hundreds of years more or less reflect this.

With these points in mind, the steady-state approach is suited for examining how valley topography may affect low-frequency, high-amplitude responses of glaciers to changes in mass balance because the problem is reduced to a geometric one. It is similar to the approach of Mercer (1962[b]) in that it considers area-elevation "requirements" for ablation, given a 
particular mass accumulation and given the restrictions which topography places on where the ablation zone can and cannot expand or contract. Moreover, this geometric link is a necessary part of combining observations of present glaciers with Quaternary interpretations, particularly in evaluating timedistance diagrams from adjoining valleys with distinct geometries (e.g. Miller, unpublished).

\section{GLACIER HYPSOMETRY AND MASS BALANCE}

Some of the equations discussed in this section can be derived directly from the works of Kurowski (1981), Osmaston (1975), and LaChapelle (1962). However, we develop them in full to maintain a focus on our specific objectives. Three assumptions, the first and third to be examined later, apply to the following discussion:

(i) the net mass-balance curve (water-equivalent depth in relation to elevation) of a glacier can be approximated as two linear functions above (accumulation zone) and below \$ablation zone) the ELA;

(ii) the net mass-balance curve reflects a stationary condition; and

(iii) valley topography sufficiently confines the glacier such that a change in mass balance (from one to another stationary condition) is accompanied by a purely elevational response (from one to another steady state) in the terminus - i.e. cross-valley variations in accumulation and ablation, at a particular elevation, are accounted for in the linear balance curve.

A rectilinear coordinate system is not well suited for treatment of mass transfers over a glacier owing to the complexity of spatial variations in width, slope, and axial distance for most glaciers. Alternatively, the hypsometric curve of a glacier's planimetric area in relation to elevation (Fig. 2) defines, in a two-dimensional manner, the factors necessary for a functional treatment of surface mass transfers. Moreover, it will be shown that the graphical display of hypsometry, which is easily constructed from topographic maps, can yield useful information concerning glacier regimen - despite the fact that the geometries of most glaciers cannot be precisely mathematically defined.
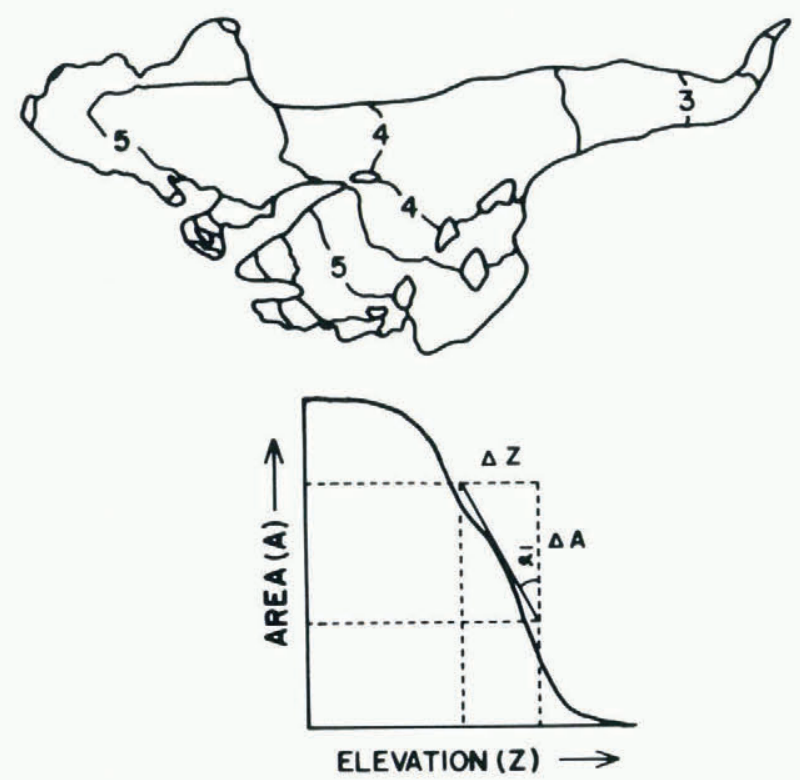

Fig. 2. Hypsometric curve $F(z)$ relating the distribution and of glacier surface area $A$ to elevation $z$. Note complexity of width, surface slope, and axial distance on topographic map of glacier (contow interval equals 500 feet; values in thousands of feet, one foot is $0.305 \mathrm{~m}$ ).
Let $F(z)$ represent the hypsometric relationship of area $A$ to elevation $z(F i g .2)$. The slope of $F(z)$ is given by

$$
\frac{\mathrm{dA}}{\mathrm{dz}}=\mathrm{L} \cot \bar{\alpha}
$$

where $L$ is the contour length and $\alpha$ is the mean surface slope at a particular elevation on the glacier. Thus, if $f(z)=F^{\prime}(z)$, and letting $g(z)$ and $h(z)$ represent the net mass-balance curves for the accumulation and ablation zones respectively,

$$
\int_{z_{m}}^{E L A} f(z) g(z) d z+\int_{E L A}^{z_{t}} f(z) h(z) d z=0
$$

where $z_{m}$ is the maximum glacier elevation and $z_{t}$ is the terminus-position elevation. Equation (2) states simply that the sum of the mass volumes accumulated and ablated equals zero for a steady-state condition. Rearranging Equation (2),

$$
\int_{E L A}^{z t} f(z) h(z) d z=\int_{E L A}^{z_{m} m} f(z) g(z) d z,
$$

so that the ELA may be considered a reference elevation. Using the Mean Value Theorem, Equation (3) may be written as

$$
h\left(c^{\prime}\right) \int_{E L A}^{z t} f(z) d z=g\left(c^{\prime \prime}\right) \int_{E L A}^{z_{m}} f(z) d z
$$

where $c^{\prime}$ and $c^{\prime \prime}$ are particular values of $z$. Because the integrands of Equation (4) are equal to the total area of the ablation zone $A_{b}$ and the area of the accumulation zone $A_{c}, h\left(c^{\prime}\right)$ and $h\left(c^{\prime \prime}\right)$ must equal the areally-weighted mean water-equivalent depths, $\bar{d}_{b}$ and $\bar{d}_{c}$, for the ablation and accumulation zones respectively. Thus Equation (4) may be simply written

$$
\bar{d}_{b} A_{b}=\bar{d}_{c} A_{c} \text {. }
$$

The elevation values $c^{\prime}$ and $c^{\prime \prime}$ (hereafter denoted by $\bar{z}_{b}$ and $\bar{z}_{c}$ ) are given by

$$
\bar{z}_{b}=\frac{1}{A_{b}} \int_{E L A}^{z_{A} t} z f(z) d z
$$

and

$$
\bar{z}_{C}=\frac{1}{A_{C}} \int_{E L A}^{z_{m}} z f(z) d z
$$

where, for convenience, $\bar{z}_{b}$ and $\bar{z}_{c}$ are measured from the ELA as positive values. It is noted that the integrands of Equations (6) and (7) are geometric moments.

Now, because $g(z)$ and $h(z)$ must pass through the values $\bar{d}_{c}$ and $\bar{d}_{b}$, it follows that the gradients, $b_{n c}$ and $b_{n b}$, of the curves $g(z)$ and $h(z)$ are defined as

$$
b_{n c}=\frac{\bar{d}_{c}}{\bar{z}_{c}}
$$

$$
b_{n b}=\frac{\bar{d}_{b}}{\bar{z}_{b}}
$$


From Equations (5), (8), and (9),

$$
\frac{b_{n b}}{b_{n c}}=\frac{\bar{z}_{c} A_{c}}{\bar{z}_{b} A_{b}}
$$

or equivalently

$$
\frac{b_{n b}}{b_{n c}}=\frac{m_{c}}{m_{b}}
$$

where $\mathrm{m}_{c}$ and $\mathrm{m}_{\mathrm{b}}$ are geometric moments.

Equation (1) describes the interrelation between the mass balance of a glacier and the distribution of its surface area over elevation. That is, given that the initial assumption ( $i$ ) is met, Equation (10) must be satisfied for a steady-state condition. But Equation (10) also reflects the indeterminacy of the interrelationship; assuming momentarily that the ratio $\mathrm{b}_{\mathrm{nb}} / \mathrm{b}_{\mathrm{nc}}$ (balance ratio BR) is fixed, an infinity of values of the remaining variables can satisfy Equation (10). However, the fundamental information contained in Equation (10) is that for a particular balance ratio, a steady-state condition is most likely to be achieved by concomitant adjustment of the moment terms, $A$ and $\bar{z}$. Moreover, by setting the value of the balance ratio and the values of $\bar{z}_{C}$ and $A_{C}$ (which is equivalent to setting the ELA for a particular area of accumulation), the importance of valley topography becomes clear. The values of $\bar{z}_{b}$ and $A_{b}$, and hence the terminus altitude (TA), becomes essentially set by the physical limits of the valley floor and walls to the extent that ice must fill the valley until an equality between mass input and output is achieved. This notion is, of course, not new. It is the basis for introducing ideas of mass transfer and balance in most texts (e.g. Sugden and John, 1976; Paterson, 1981). However, by explicitly expressing this relationship in terms of elevational geometric moments, insight may be gained concerning long-term response to changes in mass balance.

\section{LONG-TERM STABILITY AND RESPONSE}

Meier and Post (1962), Meier and Tangborn (1965), and Dugdale (1972) suggest that the form of the net mass-balance curve may be taken as characteristic of a glacier and its surrounding climate, and that yearto-year fluctuations appear as shifts along the massdepth axis. The assumption of long-term stationarity implies, however, that the flow dynamics of a glacier filter these high-frequency fluctuations, so that changes in mass balance may be considered to be the result of: (1) a vertical translation of the netbalance curves, which is equivalent to a simple change in the ELA, (2) a rotation of either or both the accumulation $g(z)$ and ablation $h(z)$ net-balance curves (in the same or opposite directions), or (3) some combination of the previous two. This is to say that a change in the mass-balance curve of an individual glacier is not likely to be produced only by climatic factors (regional and local) in the absence of modification from changing flow factors. Moreover, it is unlikely that a glacier will respond only by expansion or contraction of its terminus without modification in geometry elsewhere. This must be borne in mind in the following discussion of glacier response which incorporates the simplification of assumption (iii) from the previous section.

Following Osmaston (1975), five basic geometric forms of glaciers are considered (Fig. 3). For convenience, these idealized glaciers are approximately the same size and have the same relief. It should be noted that the forms in Figure 3 represent more accurately valley-basin shapes which may or may not be filled with glacier ice depending upon the ELA position and mass-balance gradients. By fixing the
ELA and mass-balance curves over all five glaciers, terminus elevations may be determined. Moreover, the results of allowing the ELA to successively change may be generalized as in Figure 4. Considering the direction of change to be a decreasing ELA, disparate responses in the terminus elevations may be examined in terms of Equation (10).

The relationship between ELA and TA is perfectly linear for the rectangular glacier shape. This simple, but not insignificant, relation occurs because $F^{\prime}(z)=f(z)$ is in this case a constant (Fig. 3 ). Expanding Equation (10b)

$$
\frac{b_{n b}}{b_{n c}}=B R=\frac{\int_{E L A}^{z_{m}} z f(z) d z}{\int_{E L A}^{z} z f(z) d z} .
$$

(It is noted that Equation (11) is equivalent in form to Equation (3) of LaChapelle (1962) for a net budget $B=0$.)

But $f(z)$ is a constant, so

$$
B R=\left(\frac{z_{m}-E L A}{E L A-z_{t}}\right)^{2}
$$

or

$$
z_{t}=K^{\prime} z_{c}+E L A
$$

where $K^{\prime}$ is a constant and $z_{c}=z_{m}-E L A$. Therefore,

$$
\frac{d z_{t}}{d z_{c}}=K^{\prime}
$$

and since $d z_{c}=d(E L A)\left(z_{m}\right.$ is assumed fixed)

$$
\frac{d z_{t}}{d(E L A)}=k^{\prime}
$$

which is the desired result in Figure 4. In words, a unit lowering of the ELA corresponding to an increase in accumulation is exactly compensated by a similar unit lowering of the TA (not necessarily equivalent to $\triangle E L A)$ required to ablate the increase in accumulated mass. Because $F^{\prime}(x)$ is constant, this $\triangle T A$ is inversely proportional to the balance ratio. The other shapes, of course, do not exhibit a linear response. For example, shape B (Fig. 3) is such that $F(z)$, surface area, increases at a decreasing rate. Hence, successive unit lowerings of the ELA are associated with a decreasing rate of increase in accumulated mass. But, concomitantly, the rate at which additional surface area becomes available for ablation decreases faster at lower and lower elevations. The result is that successively new requirements for ablation are compensated chiefly by increases of $\bar{z}_{b}$ relative to increases in $A_{b}$ (Equation (10a)). Thus, the TA is lower than those of other glacier forms. with the same ELA (Fig. 4). This result is very similar to the reasoning presented by Mercer (1961[b]) for fjord glaciers which, in order to achieve a steady condition, may dramatically extend their snout to a position where increased melting and calving can accommodate the increased accumulation of mass higher up. A similar, but opposite, argument can be given for glacier shape C (Fig. 3) where, because surface area increases (with decreasing elevation) at an increasing rate, the effect is relatively high terminus positions. Glacier shapes D and E are essentially end-to-end combinations of shapes $B$ and $C$. Thus, the response of $D$ to a lowering of the ELA is similar to that of $C$ over high ELA values, and similar to the 


\section{$\longleftarrow$ Flow direction}

A

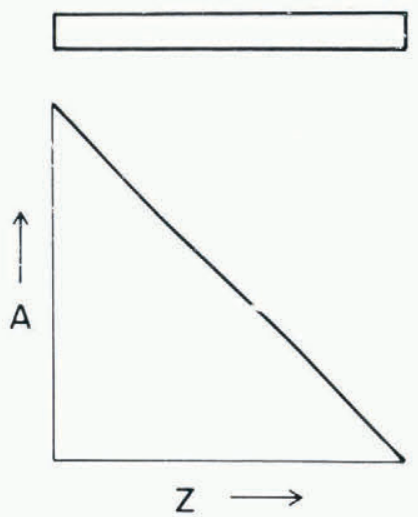

B

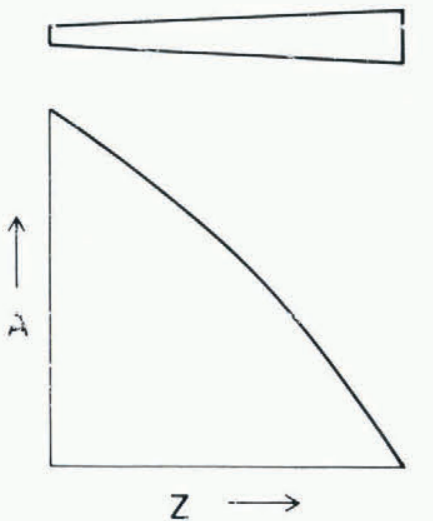

C

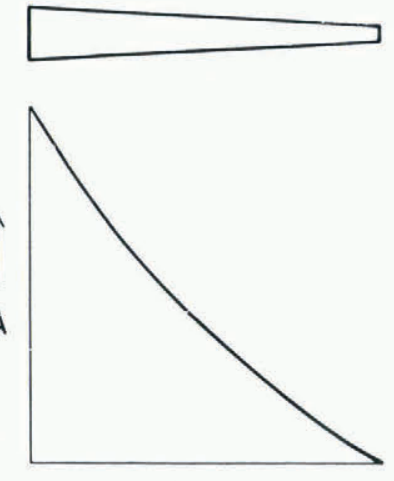

$\mathrm{Z} \longrightarrow$
D
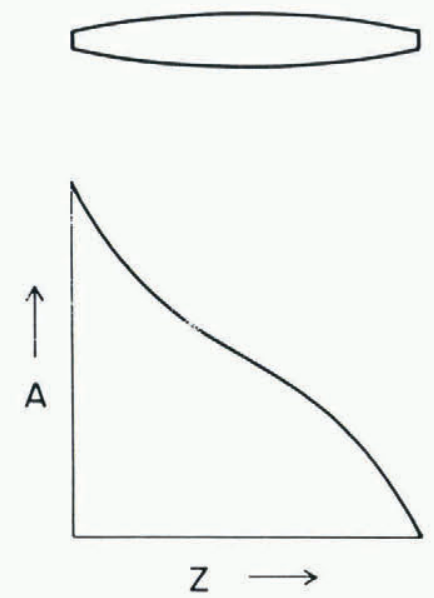

$\mathrm{E}$
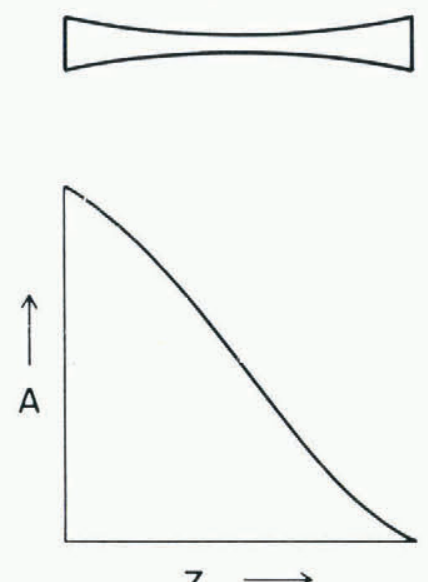

$\mathrm{Z} \longrightarrow$

Fig. 3. Planimetric views and hypsometric cueves of five basic (idealized) glacier shapes. Shapes D and E are essentially end-to-end combinations of shapes $B$ and $C$.

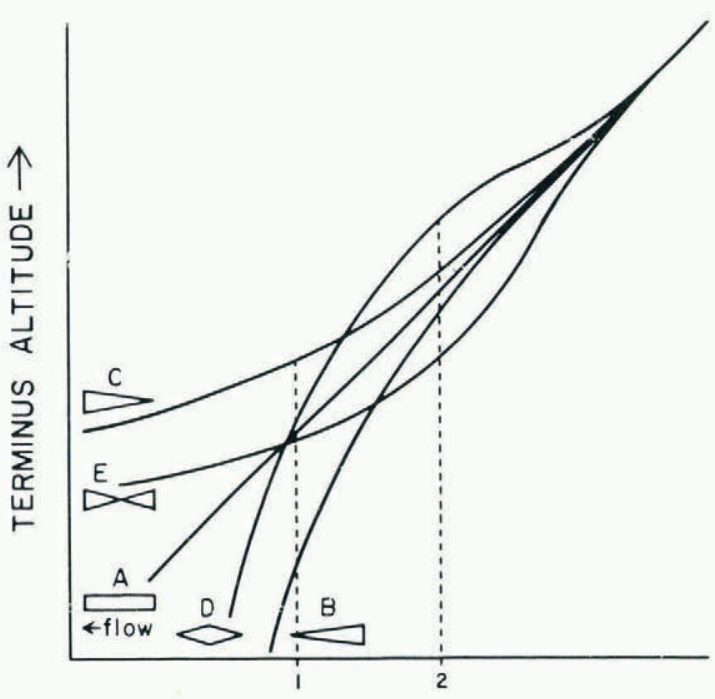

EQUILIBRIUM LINE ALTITUDE $\rightarrow$

Fig. 4. General relation between terminus altitude (TA) and ELA for the five idealized glaciers of Figure 3 . Balance ratio ( $B R$ ) is constant over the ELA range. For ELA position 1, the TA of $B<A \approx D \approx E<C$; for position 2, $E<B<A<C<D$. response of $B$ over lower ELA values. Likewise, the response of $E$ is similar to that of $B$ over high ELA values, and similar to the response of $C$ over lower ELA values (Fig. ${ }^{4}$ ).

These results also suggest that the collective responses of glaciers may contain useful climatic (mass-balance) information for a particular region. If, as depicted in Figure 4 , several glaciers within distinct valley shapes are subjected to similar climatic conditions, there should exist a more-or-less unique set of TA positions. For example, with the relative ELA position 1 in Figure 4 (assuming similar mass-balance curves), TA positions of glacier shapes $B$ and $C$ would be dissimilar whereas TA positions of $A$, $D$ and $E$ would be essentially the same. Moreover, with a change in the regional ELA, the relative "rank" of a glacier's TA position may or may not change depending on its geometry (contrast relative TA values for ELA positions 1 and 2 in Figure 4). Conversely, time-distance diagrams from distinct, but adjoining, valleys may be used, if evaluated collectively, to infer the necessary climatic conditions (or changes in climate) leading to a set of former (or present) glacier positions. We present a brief example from Miller (unpublished) in the next section.

Taking elevation as the abscissa, clockwise rotation of the $g(z)$ and $h(z)$ curves implies reduced accumulation and ablation, and counterclockwise 
rotation implies increased accumulation and ablation. These rotations also correspond to a reduction and an increase, respectively, of the values of $b_{n c}$ and $b_{n b}$. If the ELA is fixed, it is apparent from Equation (10) that changes in $b_{n c}$ or $b_{n b}$, or both, must be compensated by an increase (terminus advance) or a decrease (retreat) in the geometric moment of the ablation area. An argument similar to that given previously concerning changes in the ELA can be extended to the prediction of disparate responses between glaciers with different distributions of ablation surface over elevation. Of particular interest, however, is the special case where sympathetic rotation of $g(z)$ and $h(z)$ maintains a constant value for the balance ratio ( $\left.b_{n b} / b_{n c}\right)$. If this occurs, then according to Equation (10), glacier geometry does not change. For example, a climatic change which would translate into a doubling of both $b_{n b}$ and $b_{n c}$ would not lead to an advance or retreat. The possibility therefore exists that certain major climatic events could go undetected if reconstructions are based too heavily upon terminal-moraine positions. Such a "perfect" rotation is unlikely; a change in precipitation would have to be exactly compensated by a change in thermal energy available for melting (Kuhn, [1981]), and also, changes in geometry due to changes in flow conditions would be likely to accompany rotation. Nevertheless, if a significant long-term change in climate produced an "imperfect" multiple of change between the $b_{n b}$ and $b_{\text {pc }}$ values, the result could be the construction of closely spaced moraines, which might incorrectly be interpreted as marking minor differences in glacier regimen.

These notions of long-term glacier response, embodied in Equation (10), have practical utility. Depending upon which variables are known and which are unknown, Equation (10) may be used to infer limited information about the regimen of a modern or former glacier, or, conversely, to estimate ELA values. In general, if the ELA and terminal position of a glacier are known, and if reasonable topographical control is

available for modern glaciers (or can be reconstructed for former glaciers; e.g. Porter, 1975), then the values of $A_{c}$ and $A_{b}$ are known and $\bar{z}_{C}$ and $\bar{z}_{b}$ can be estimated numerically (Equations (6) and (7)). (We will also show in the next section that they can be approximated graphically.) This enables calculation of the balance ratio. Independent data concerning accumulation or ablation would be required, of course, to attach actual values to either $b_{n b}$ or $b_{n c}$. Conversely, if a balance ratio is assumed, ELA values can be estimated, an approach taken by Osmaston (1975) using a slightly different form of Equation (10). The strength of the relationship of Equation (10) is, in part, its use in conjunction with other independent means of estimating glacier regimen or ELA values. Additionally it can provide a simple means for using the disparate responses of several glaciers in an area to infer possible climatic influences.

\section{EXAMPLES}

Three examples of the application of Equation (10) are presented. The first concerns a simple test of Equation (10) using data of Meier and Tangborn (1965) for South Cascade Glacier. We then examine balanceratio variations over an area of the Alaska Range, and the possibility of using this ratio to estimate ELA values. Finally, we describe the work of Miller (unpublished) to illustrate how disparate responses of glaciers may be utilized to infer climatic influence.

\section{South Cascade Glacier balance ratio}

Values for Equation (10) were estimated from the topographic map of Meier and Tangborn (20 m contour interva1; correct as of 12 September 1961) for South Cascade Glacier, and from their estimate of the steady-state net-balance curve for seven budget years (Fig. 5a). The balance ratio was calculated to be about 2.2, whereas the straight-line approximations of $g(z)$ and $h(z)$ in Figure 5 a have a ratio of about

(b)

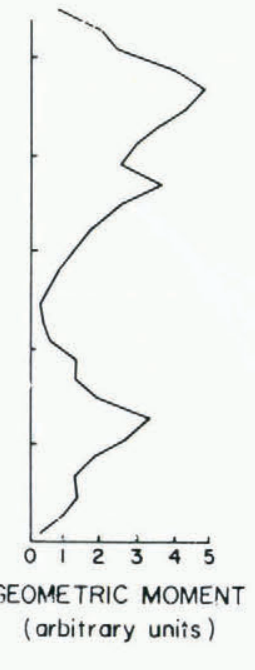

(c)

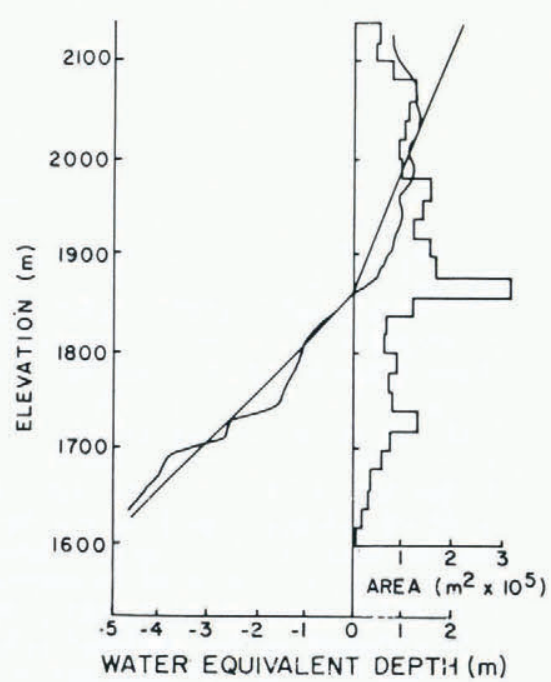

Fig. 5. (a) Steady-state net-balance curve (from budget years 1957-58 through 1963-64) and surface area in relation to elevation for South Cascade Glacier (after Meier and Tangborn, 1965). Also shown are the straightline approximations of the net-balance curve.

(b) Elevational distribution of geometric moments calculated from Equation (10).

(c) Mass volume distribution over accumulation zone

based on "true" net-balance curve (solid line) and on

linear approximations of the net-balance curve (dashed line). 
2.3. This difference would amount to less than one contour interval $(20 \mathrm{~m})$ difference in terminus altitude. We suggest that this close agreement is not fortuitous. The linear approximation of $h(z)$ (ablation zone) is very good, as has been reported for other cases (Renaud, 1952; Nielsen, 1957; Schytt, 1967; Dugdale, 1972). In contrast, the linear approximation of $g(z)$ appears less reasonable for the areas just above the ELA and over the highest elevations; this apparently common feature of glaciers is discussed by Mercer (1961[a]) and LaChapelle (1962) in terms of the use of a linear approximation. However, it should be stressed that, because geometric moments are calculated for Equation (10), these areas contribute a relatively small proportion to the momment $\mathrm{m}_{\mathrm{c}}$ of the accumulation zone (Fig. $\left.5 \mathrm{~b}\right)$. For example, $63 \%$ of $m_{c}$ is due to the distribution of area between $1940 \mathrm{~m}$ and $2080 \mathrm{~m}$ elevation, less than one-half of the total relief of the accumulation zone. Moreover, the interval of largest actual area, $1860 \mathrm{~m}$ to $1880 \mathrm{~m}$, accounts for less than two per cent of the total geometric moment, although the area over the interval is greater than $12 \%$ of the total area $A_{C}$. A similar argument can be made concerning the distribution of mass over elevation (Fig. $5 \mathrm{C}$ ). Moreover, the total mass estimated using the true balance curve and that estimated from the linear approximation of $g(z)$ differ by only about three per cent. For these reasons, it seems reasonable to conclude that the assumption of linearity is most important over the mid-elevation ranges of the two net-balance curves. We have no evidence indicating that this is not usually the case for most glaciers.

\section{Balance-ratio variation and ELA estimation}

Although a numerical solution is relatively easy to obtain, it is also possible to obtain a graphical solution of Equation (10a) from the hypsometric curve $F(z)$ of a glacier. For many glacier forms, $\bar{z}_{c}$ and $\bar{z}_{b}$ are very well approximated by the two values of $z$ associated with the mid-area values of the accumulation and ablation zones (Fig. 6$) \cdot\left(\bar{z}_{c}\right.$ and $\bar{z}_{b}$ are measured

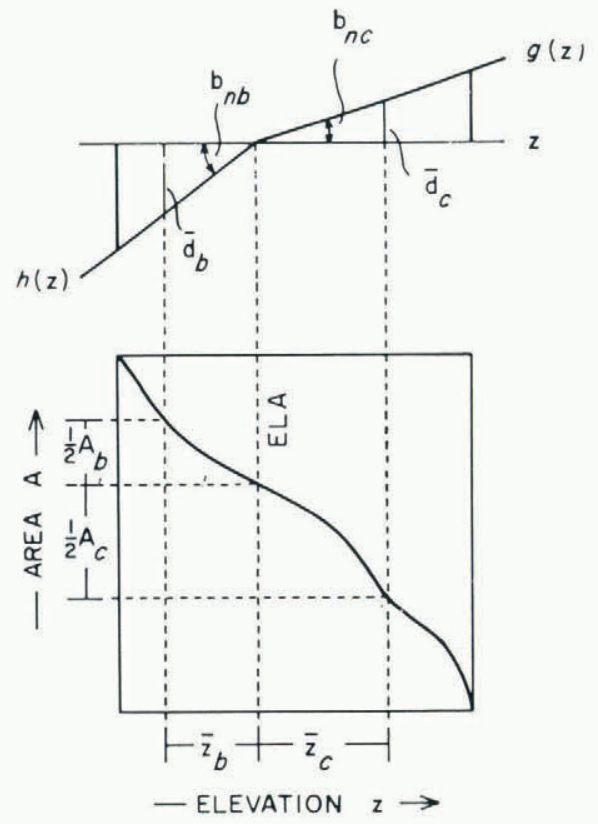

Fig. 6. Graphical solution of Equation (10a): positive distances (from ELA) of $\overline{z_{c}}$ and $\overline{z_{b}}$ are associated approximately with mid-area values of the accumulation and ablation zones; these are also associated with the areal-weighted mean water-equivalent depths $\bar{d}_{c}$ and $\bar{d}_{b}$ Lines $g(z)$ and $h(z)$ are linear approximations of the net-balance curve over elevation. as positive values from the ELA.) For example, this approximation gives elevation values of about $1960 \mathrm{~m}$ and $1770 \mathrm{~m}\left(\bar{z}_{c} \approx 100 \mathrm{~m} ; \bar{z}_{b} \approx 90 \mathrm{~m}\right)$, which leads to a balance ratio of about 2.2 for South Cascade Glacier. This approximation also allows the ELA to be readily estimated, if a particular value of the balance ratio is assumed, by interatively choosing ELA values until Equation (10a) is satisfied.

To examine this use of Equation (10), we selected three groups of glaciers within the Alaska Range for which topographic coverage was good, and from which values of ELA could be reasonably estimated, based mainly on ice-surface topography. The three groups included: ten glaciers flowing radially from the Kichatna massif; Straightway, Foraker, and Herron Glaciers, each flowing north-west off the main crest of the range; and nine glaciers located on the north flank of the range in the east-central part of McKinley National Park. These groups will be referred to, respectively, as Kichatna, West Park, and East Park (Figs 7 and 8 ). The glaciers exhibit a wide range in areal geometry (Fig. 9), and have a similar geographic setting within each group. The following were determined or calculated for each glacier (Table I): maximum elevation $z_{m}$, minimum elevation $z_{t}$, total area, ELA, accumulation-area ratio (AAR) based on graph of hypsometric curve; AAR based on numerical solution with linear interpolation; balance ratio (BR) based on half-area approximations of $\bar{z}_{\text {and }} \bar{z}_{b}$; and balance ratio based on numerical solution (linear interpolation). Additionally, ELA values were back-estimated assuming first, an AAR of 0.65 , and second, a BR of 2.0. ( $A$ value of 2.0 was chosen based on initial estimates of BR from the Kichatna group.) It should also be emphasized that ELA values were initially estimated from the topographic maps based mainly on ice topography, being where contour lines change from concave to convex down-valley. We felt that this would give the best indication of a steady-state ELA. Moreover, where ELA values did not coincide between tributary valleys, we attempted to choose a single ELA value which reflected an areal weighting of the tributary valleys. This occurred infrequentiy.

(1) Concerning methodology, there is close agreement between the graphical and numerical solutions, as reflected in AAR and BR values (Table I; Fig. 10). Thus, expediency becomes a guide for choosing one or the other method. We used the graphical solutions for the comparisons discussed next.

(2) Several approaches have been taken to estimate former ELA values (e.g. Mercer, 1961[a]; Porter, $1970,1975)$. A comprehensive review and comparison (by trend-surface analysis) of six methods are presented by Meierding (1982) for the Colorado Front Range. Gross and others ([1977]) also compare eight frequently used methods that show varying results; the most reliable, based on a "standard" calculation of $A A R=0.67$, apparently comes from lateral moraine positions. This result is not in agreement with the results from Hawkins (unpublished) and Meierding (1982) and may depend on special conditions for the preservation of lateral moraine remnants. Given the data in Table I, it is worthwhile to consider the usage of AAR values in particular because of their frequent use for reconstructing former ELAs and because this method relies implicitly upon similarity of glacier shape and regimen over a given geographic area. This may be illustrated by considering, first, the idealized glaciers in Figure 3. If a balance ratio of 2.0 is applied to each shape (where each has $1000 \mathrm{~m}$ relief), AAR values range between 0.55 and 0.63 for an ELA at $500 \mathrm{~m}$. Moreover, the AAR of glacier shape $E$, for example, changes from 0.59 for an ELA at $500 \mathrm{~m}$ to 0.63 for an ELA at $800 \mathrm{~m}$. This clearly illustrates the sensitivity of AAR values to hypsometry, particularly considering that the hypsometric curves of Figure 3 are innocuous relative to those of most natural glaciers. The possibility exists for describing 


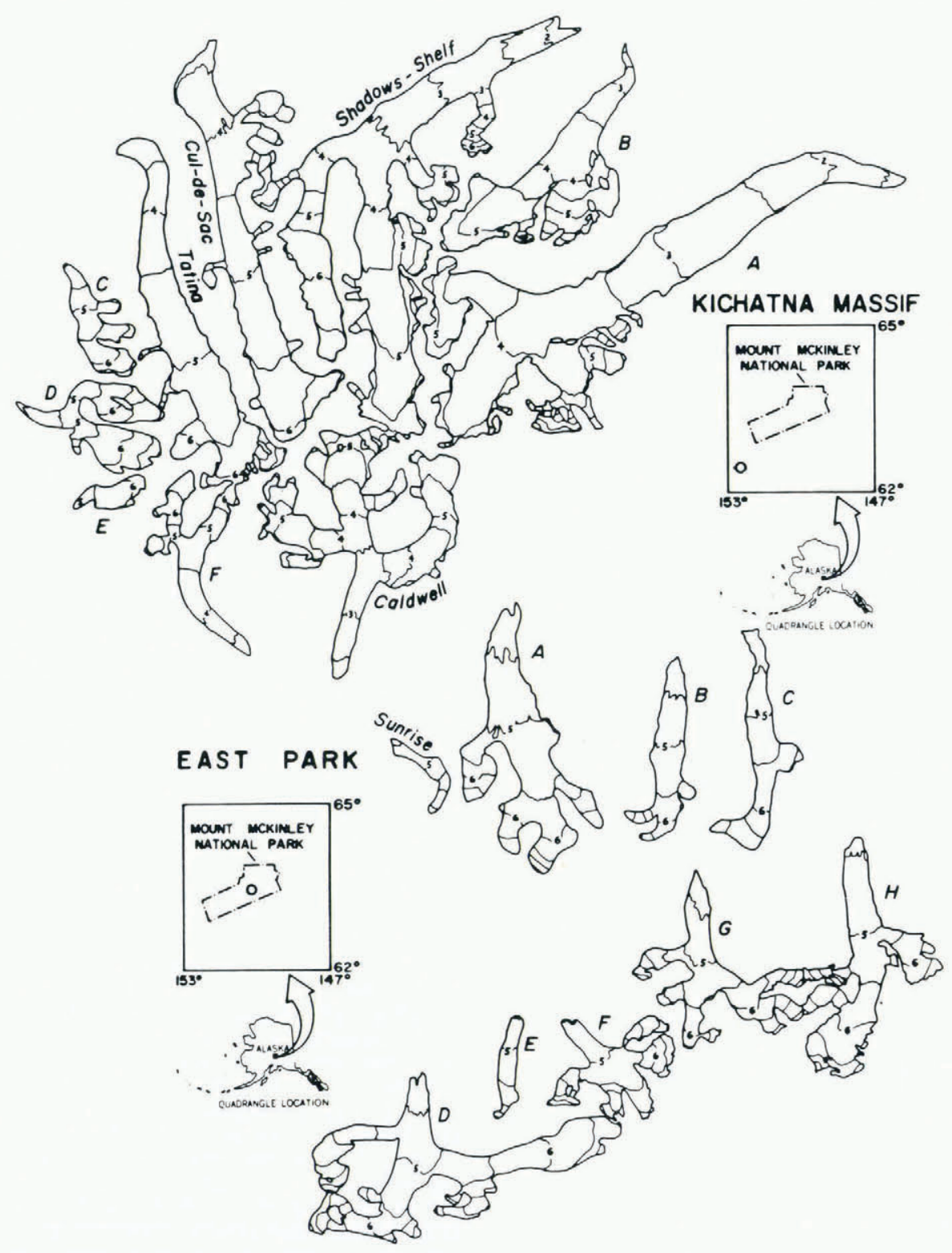

Fig. 7. Topographic and location maps of the ten Kichatna massif glaciers and the nine East park glaciers used to evaluate Equation (10). Contous interval equals 500 feet; values in thousands of feet. 


\section{WEST PARK}

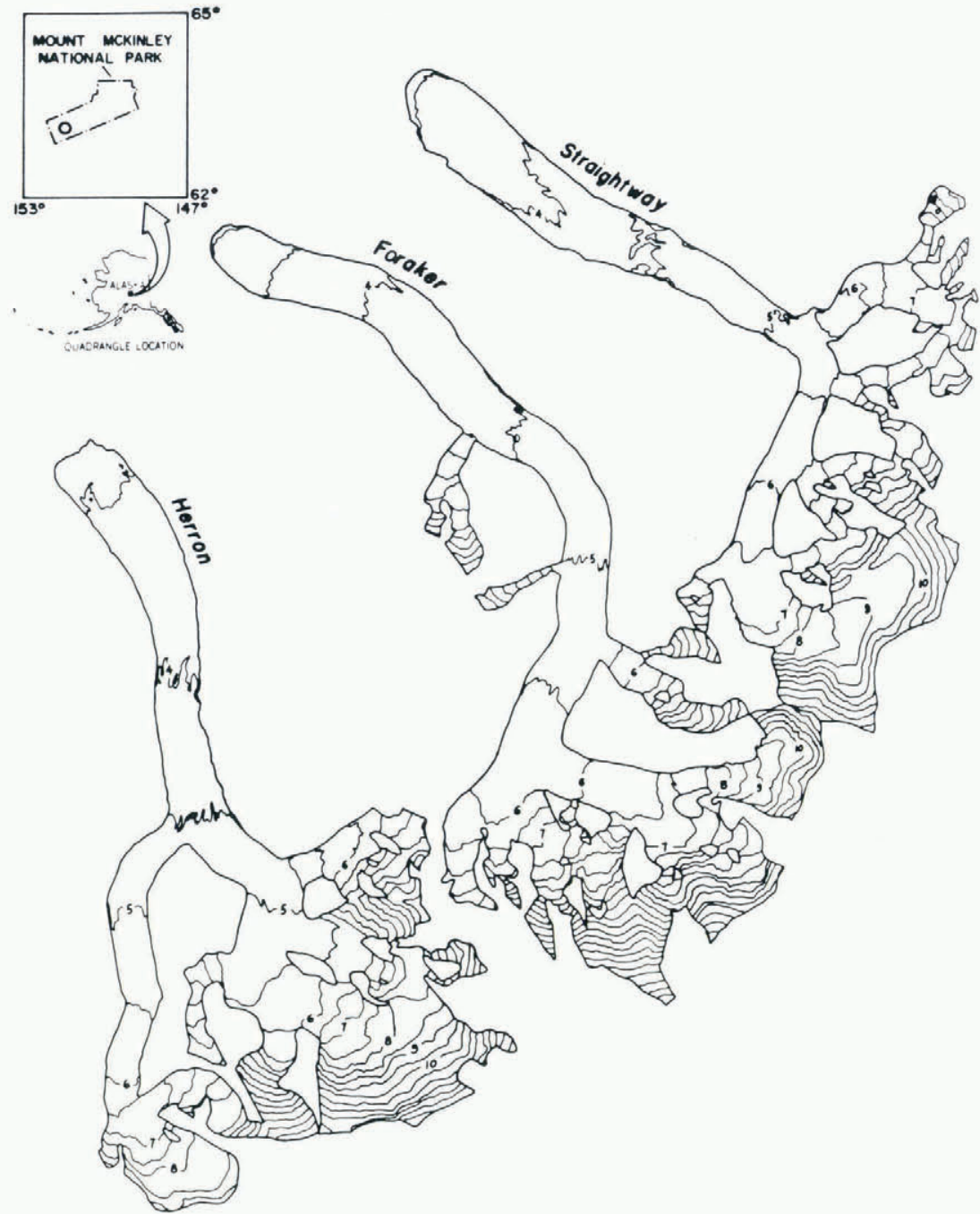

Fig. 8. Topographic and location maps of the three West park glaciers used to eval uate Equation (10). Contour interval equals 500 feet; values in thousands of feet. 
KICHATNA MASSIF
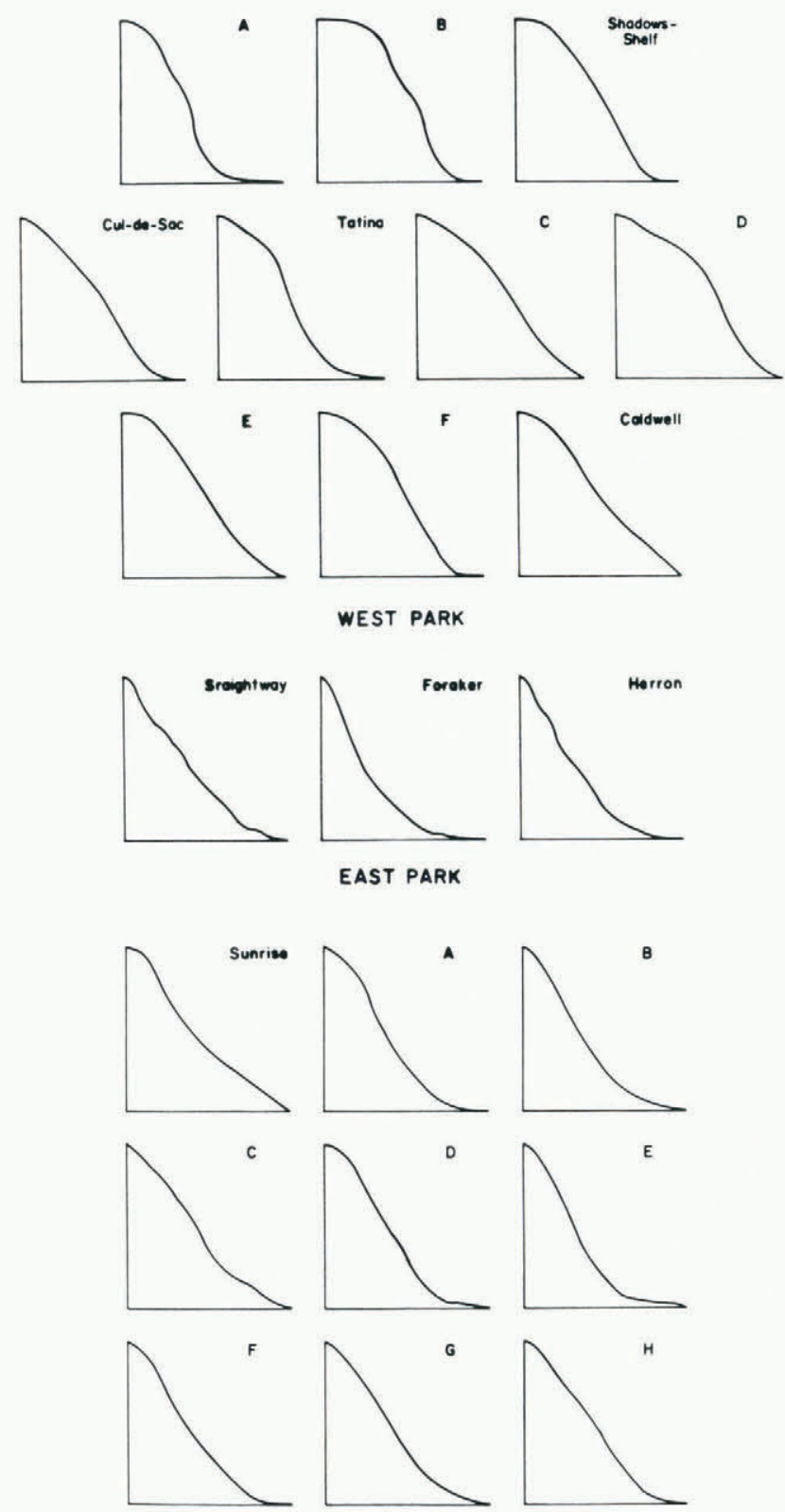

Fig. 9. Hypsometric curves of the Kichatna massif, West Park, and East Park glaciers. Elevation ranges and areas are given in Table $I$.

families of curves for which particular AAR values more or less apply. However, hypsometric curves are not easily parameterized for the purpose of distinguishing certain "types". Moreover, this approach would ignore differences in BR values, or more accurately, spatially varying rates of accumulation and ablation (Mercer, 1961[a]).

Thus, geographic setting (e.g. maritime) may be a tenuous guide for choosing a particular AAR value for ELA estimations. Our ELA estimates for this area of the Alaska Range, based on an AAR of 0.65 , show a wide range in error (Table I). A particularly noteworthy example is the difference between the Kichatna and West Park groups. The Kichatna glaciers (Figs 7 and 9) generally have hypsometric curves like shape D (Fig. 3), and AAR values which cluster around 0.62 . In contrast, the three West Park glaciers, which are very close in size (Figs 8 and 9), are "strong" Cshapes with nearly identical AAR values of about 0.52 . The ELA estimate errors consistently reflect this hypsometric contrast (Table I).

(3) ELA estimates based on an assumed balance ratio of 2.0 appear, overall, to be less in error (Table I). By itself, this does not suggest superiority of this approach; an a priori choice of a lower AAR value would have consistently improved the first set of ELA estimates. (Likewise, a lower BR value would improve, overall, the second set.) The problem concerning reconstruction, in the absence of mass-balance data, becomes a question of which assumption (a particular AAR or BR) would better represent a set of glaciers in a similar geographic setting. As shown by the general relations in Figure 11, ELA estimate error is proportional to the inaccuracy of each of the initial assumptions.

(4) It has been suggested that steady-state indices of glacier regimen (e.g. energy of glacierization) ought to be characteristic of a number of glaciers within a similar geographic setting (e.g. Shumskiy, 1946; LaChapelle, 1962). This presents the possibility that BR values could be estimated from glaciers for which data were available (e.g. ELA estimates based on maximum lateral moraine elevation) to be applied to other glaciers. The use of a BR in this manner rests on the assumption that although the $B R$ is linked to topography through mass balance (Fig. 1), glacier hypsometry per se would be unlikely to contribute to variations in the BR. This is in contrast with the direct linkage between hypsometry and AAR values discussed previously. Viewed in this manner, the ELA estimates based on an assumed ratio of 2.0 (Table I) appear very promising. With the exception of five glaciers, all error estimates fell within $\pm 40 \mathrm{~m}$. All but four fell within $\pm 50 \mathrm{~m}$. (One of these, Straightway, exhibits an unusually irregular ablation topography. It also has no Neoglacial terminal-moraine sequence, in contrast to well-defined sequences associated with the Foraker and Herron Glaciers (personal communication from C. Waythomas). This may indicate a prehistoric surge which would have the effect of reducing the "true" steady-state balance ratio, thereby giving a large ELA estimate error.) Our assumption of $B R=2.0$ was largely the consequence of the order in which the data of Table I were collected, namely, we chose the mean BR value of the Kichatna group. This luxury of course would be unlikely to be available for reconstruction purposes. Nevertheless, data of this type, particularly for modern glaciers, are becoming more available for various parts of the world (e.g. Meier and others, 1971; Müller, 1977).

(5) Balance ratios exhibit a wide range of values, particularly within the East Park group (Table I). In addition to error associated with estimating the BR from topographic maps, a size-associated variation should also be expected (Fig. 12). Different sizes of glaciers may be out of phase, in terms of how their geometry and topography reflect certain lengths of historical mass and energy exchanges, due to different lag times (LaChapelle, 1965; Miller, 1973). Thus, because our work was done with a single "snapshot" of modern glaciers, ice topography could be unreliable for small glaciers as an indicator of long-term ELA values. Additionally total relief is small so that errors in estimated ELA values could be translated into significant deviations of the calculated BR values from true values. Evaluation of this error is difficult. These points suggest that the premise of a characteristic regimen index for a region requires further examination.

\section{Disparate responses of glaciers}

The utilization of disparate responses to infer climatic influence is well illustrated by the work of Miller (unpublished). He used moraine positions associated with two distinct glacier shapes to infer 

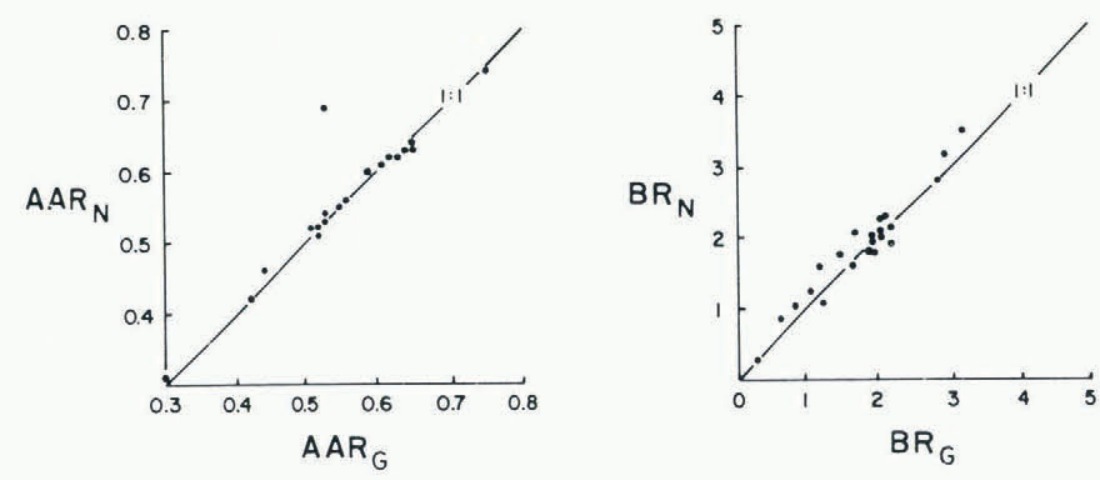

Fig. 10: Relations between values of $A A R$ and $B R$ determined numerically $(N)$ and graphically (G) for the 22 glaciers studied (Table I). The 1:1 lines represent perfect agreement between methods.

TABLE I. ELEVATION, AREA, ELA, AAR, AND BR DATA FOR THE KICHATNA MASSIF, WEST PARK, AND EAST PARK GLACIERS, ALASKA RANGE. DATA ARE BASED ON 1 INCH TO 1 MILE $(1: 63360)$ TOPOGRAPHIC MAPS (CON TOUR INTERVAL OF 100 FEET)

\begin{tabular}{|c|c|c|c|c|c|c|c|c|c|c|}
\hline Glacier & $\begin{array}{l}z_{M} \\
m\end{array}$ & $\begin{array}{l}\mathrm{Z}_{\mathrm{T}} \mathrm{T} \\
\mathrm{m}\end{array}$ & $\begin{array}{l}\text { Area } \\
\mathrm{km}^{2}\end{array}$ & $\underset{\mathrm{m}}{\mathrm{ELA}}$ & $\mathrm{AAR}_{G}$ & AARN $_{N}$ & $\mathrm{BB}_{G}$ & $B R_{N}$ & AAR $_{0.65}$ & $\mathrm{BR}_{2.0}$ \\
\hline $\begin{array}{l}\text { KICHATNA } \\
\text { A } \\
\text { B } \\
\text { Shadows-Shelf } \\
\text { Cul-de-sac } \\
\text { Tatina } \\
\text { C } \\
\text { D } \\
\text { E } \\
\text { F } \\
\text { Caldwell } \\
\text { mean values } \\
\end{array}$ & $\begin{array}{l}2440 \\
2010 \\
2290 \\
2130 \\
2350 \\
2040 \\
2190 \\
1980 \\
2100 \\
2160 \\
2170 \\
\end{array}$ & $\begin{array}{r}310 \\
490 \\
410 \\
990 \\
930 \\
1200 \\
1140 \\
1430 \\
940 \\
640 \\
850 \\
\end{array}$ & $\begin{array}{r}25.92 \\
9.39 \\
24.17 \\
14.43 \\
11.15 \\
2.54 \\
4.47 \\
0.94 \\
4.08 \\
12.39 \\
10.95 \\
\end{array}$ & $\begin{array}{l}1070 \\
1280 \\
1280 \\
1430 \\
1460 \\
1580 \\
1620 \\
1710 \\
1460 \\
1310 \\
1420 \\
\end{array}$ & $\begin{array}{l}0.62 \\
0.61 \\
0.61 \\
0.62 \\
0.64 \\
0.65 \\
0.75 \\
0.53 \\
0.53 \\
0.63 \\
0.62 \\
\end{array}$ & $\begin{array}{l}0.62 \\
0.61 \\
0.61 \\
0.62 \\
0.63 \\
0.63 \\
0.74 \\
0.69 \\
0.54 \\
0.62 \\
0.63 \\
\end{array}$ & $\begin{array}{l}1.52 \\
2.19 \\
1.90 \\
2.04 \\
1.94 \\
2.18 \\
3.15 \\
1.27 \\
1.94 \\
2.07 \\
2.02 \\
\end{array}$ & $\begin{array}{l}1.77 \\
1.91 \\
1.80 \\
2.08 \\
2.02 \\
2.15 \\
3.51 \\
1.09 \\
1.80 \\
1.98 \\
2.01 \\
\end{array}$ & $\begin{array}{r}-40 \\
-30 \\
-60 \\
-30 \\
-10 \\
0 \\
+90 \\
-50 \\
-70 \\
-10 \\
-20 \\
\end{array}$ & $\begin{array}{r}-20 \\
+20 \\
-20 \\
0 \\
0 \\
-30 \\
+190 \\
-20 \\
0 \\
0 \\
+10 \\
\end{array}$ \\
\hline $\begin{array}{l}\text { WEST PARK } \\
\text { Straightway } \\
\text { Foraker } \\
\text { Herron } \\
\text { mean values } \\
\end{array}$ & $\begin{array}{l}3800 \\
5300 \\
4270 \\
4460 \\
\end{array}$ & $\begin{array}{l}970 \\
880 \\
940 \\
930 \\
\end{array}$ & $\begin{array}{l}50.10 \\
58.37 \\
61.59 \\
56.69 \\
\end{array}$ & $\begin{array}{l}2010 \\
1860 \\
1800 \\
1890 \\
\end{array}$ & $\begin{array}{l}0.51 \\
0.52 \\
0.52 \\
0.52 \\
\end{array}$ & $\begin{array}{l}0.52 \\
0.51 \\
0.52 \\
0.52 \\
\end{array}$ & $\begin{array}{l}1.09 \\
2.11 \\
1.71 \\
1.64 \\
\end{array}$ & $\begin{array}{l}1.26 \\
2.30 \\
2.08 \\
1.88 \\
\end{array}$ & $\begin{array}{l}-280 \\
-220 \\
-190 \\
-230 \\
\end{array}$ & $\begin{array}{r}-180 \\
+20 \\
-10 \\
-60 \\
\end{array}$ \\
\hline $\begin{array}{l}\text { EAST PARK } \\
\text { Sunrise } \\
\text { A } \\
\text { B } \\
\text { C } \\
\text { D } \\
\text { E } \\
\text { F } \\
\text { G } \\
\text { H } \\
\text { mean values } \\
\end{array}$ & $\begin{array}{l}2040 \\
2330 \\
2230 \\
2240 \\
2510 \\
2160 \\
2330 \\
2390 \\
2390 \\
2290 \\
\end{array}$ & $\begin{array}{l}1300 \\
1240 \\
1260 \\
1270 \\
1260 \\
1360 \\
1360 \\
1280 \\
1310 \\
1290 \\
\end{array}$ & $\begin{array}{r}0.99 \\
9.41 \\
3.51 \\
3.85 \\
11.52 \\
1.07 \\
4.60 \\
5.72 \\
8.01 \\
5.41 \\
\end{array}$ & $\begin{array}{l}1740 \\
1620 \\
1620 \\
1650 \\
1680 \\
1620 \\
1650 \\
1580 \\
1740 \\
1660 \\
\end{array}$ & $\begin{array}{l}0.30 \\
0.53 \\
0.42 \\
0.55 \\
0.56 \\
0.44 \\
0.59 \\
0.65 \\
0.61 \\
0.52 \\
\end{array}$ & $\begin{array}{l}0.31 \\
0.53 \\
0.42 \\
0.55 \\
0.56 \\
0.46 \\
0.60 \\
0.64 \\
0.61 \\
0.52 \\
\end{array}$ & $\begin{array}{l}0.28 \\
1.69 \\
0.64 \\
1.22 \\
1.97 \\
0.85 \\
2.81 \\
2.90 \\
2.05 \\
1.60 \\
\end{array}$ & $\begin{array}{l}0.29 \\
1.61 \\
0.87 \\
1.60 \\
1.95 \\
1.05 \\
2.81 \\
3.18 \\
2.27 \\
1.74 \\
\end{array}$ & $\begin{array}{r}-240 \\
-60 \\
-120 \\
-60 \\
-50 \\
-80 \\
-40 \\
0 \\
-110 \\
-80 \\
\end{array}$ & $\begin{array}{r}-160 \\
-20 \\
-80 \\
-40 \\
0 \\
-50 \\
+30 \\
+40 \\
0 \\
-30 \\
\end{array}$ \\
\hline overall means & 2530 & 1040 & 14.92 & $\underline{1580}$ & $\underline{0.56}$ & $\underline{0.57}$ & $\underline{1.80}$ & 1.88 & -80 & -20 \\
\hline
\end{tabular}

differences in mass balance for Late Foxe/Wisconsinan and Neoglacial glaciers on north-eastern Baffin Island. Miller described "foot" and "potbelly" glaciers. A foot glacier has a large upland accumulation area which leads down-valley through a steep "neck" to a piedmont ablation lobe (E, Fig. 3); the Neoglacial terminal moraine is usually nested closely within the Late Foxe/Wisconsinan moraine, and the present ice terminus essentially abuts the Neoglacial moraine. In contrast, former potbelly glaciers had relatively little upland accumulation areas, but large midsection areas (D, Fig. 3); the associated modern glac- iers frequently occur only as small ice bodies in upland areas, far removed from the Late Foxe/ Wisconsinan and Neoglacial maxima. In fact, Miller inferred from this and other evidence that the two responses in terminus positions were most likely to be associated with a nearly $200 \mathrm{~m}$ increase in the ELA, and an increase in precipitation and summer temperatures, suggesting a sympathetic rotation of $\mathrm{g}(\mathrm{z})$ and $h(z)$. Analyses of this type could easily benefit from an iterative computer program that incorporates the simplicity of Equation (10).

As noted previously in reference to Figure 4 , the 
A

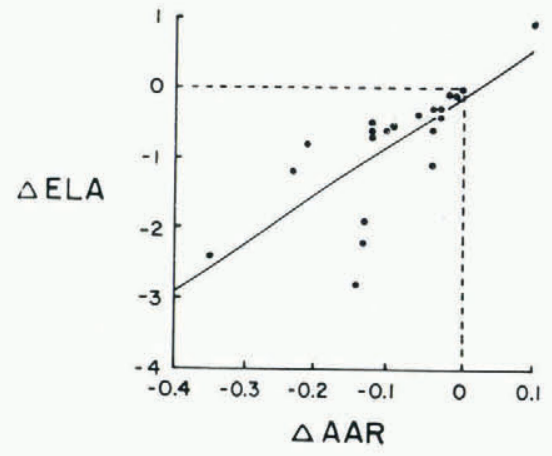

B

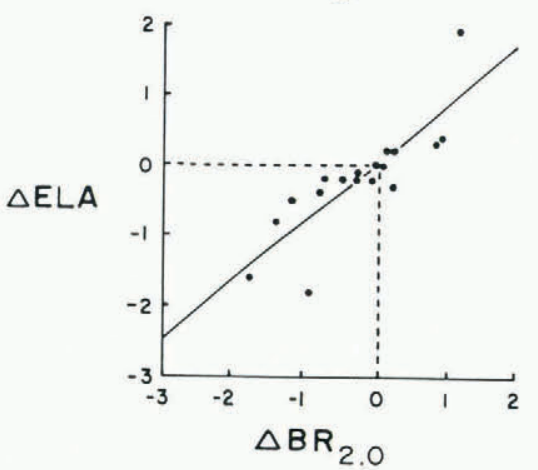

Fig. 11. Least-squares relations between deviations of estimated ELA from "true" ELA values and deviations of (a) "true" AAR values from 0.65 , and (b) "true" BR values from 2.0 . Data apply to the 22 glaciers studied (Table I). Dashed lines intersect at zero "error".

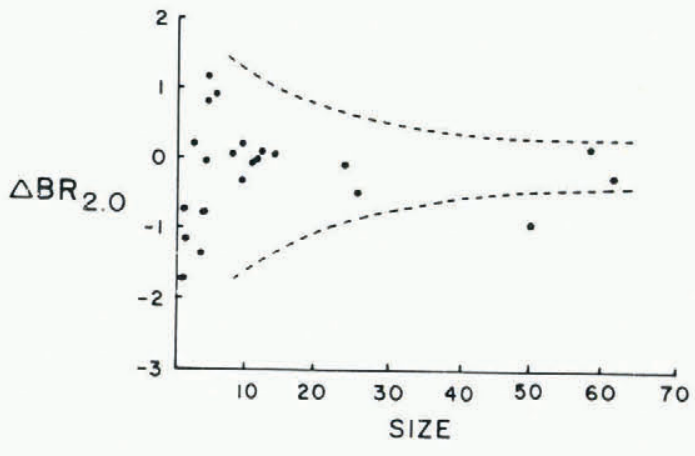

Fig. 12. Plot of deviations of "true" BR values from 2.0 for the 22 glaciers studied (Table I) in relation to glacier size $\left(\mathrm{km}^{2}\right)$. The data mildly suggest the envelope curves (dashed lines); the outlier near $50 \mathrm{~km}^{2}$ is straightway Glacier (see text for discussion).

relative amount of response (advance or retreat) of varying glacier shapes may change as the regional ELA changes. This suggests that the most highly contrasting shapes in a region would yield the greatest information concerning climatic influence on glacier response (Miller, unpublished). It also suggests that independent estimates of former ELA values, for example using a particular AAR value, should initially be made from glaciers with similar shapes and altitudinal ranges when a large sample size can be obtained.

\section{ACKNOWLEDGEMENTS}

We thank E.R. LaChapelle, S. Lehman, G. Miller, and $C$. Waythomas for critical comments concerning our research. An anonymous reviewer provided an unusually thorough evaluation of our work, which we greatly appreciate. We also thank James Walters for drafting the figures.

\section{REFE RENCE S}

Allison, I.F., and Kruss, P.D. 1977. Estimation of recent climate change in Irian Jaya by numerical modeling of its tropical glaciers. Aretic and $A l$ pine Research, Vol. 9, No. 1, p. 49-60.

Andrews, J.T. [ $\left.{ }^{C} 1975.\right]$ Glacial systems. An approach to glaciers and their environments. North Scituate, Mass., Duxbury Press.
Andrews, J.T., and others. 1970. An inventory of the present and past glacierization of Home Bay and Okoa Bay, east Baffin Island, N.W.T., Canada, and some climatic and palaeoclimatic considerations, by J.T. Andrews, R.G. Barry, and L. Drapier. Journal of Glaciology, Vol. 9, No. 57, p. 337-62.

Budd, W.F., and Jenssen, D. [1975.] Numerical modelling of glacier systems. [Union Géodésique et Géophysique Internationale. Association Inter nationale des Sciences Hydrologiques. Commission des Neiges et Glaces.] Symposium. Neiges et Glaces. Actes du colloque de Moscow, août 1971, p. 257-91. (IAHS-AI SH Publication No. 104.)

Dugdale, R.E. 1972. A statistical analysis of some measures of the state of a glacier's "health". Joumal of Glaciology, Vol. 11, No. 61, p. 73-79.

Gross, G., and others . [1977.] Methodische Untersuchungen über die Schneegrenze in alpinen Gletschergebieten, von G. Gross, H. Kerschner, und G. Patzelt. Zeitschrift für Gletscherkunde und Glazialgeologie, Bd. 12, Ht. 2, 1976, p. 223-51.

Hawkins, F.F. Unpublished. Glacial geology and late Quaternary paleoenvironment in the Merchants Bay a rea, Baffin Island, N.W.T., Canada. [M.Sc. thesis, University of Colorado, Boulder, 1980.]

Kuhn, M. [1981..] Climate and glaciers. [Union Géodésique et Géophysique Internationale. Association Internationale des sciences Hydrologiques. ] Sea level, ice, and climatic change. Proceedings of the symposium held ?-8 December 1979 during the 17th general assembly of the Internatioal Union of Geodesy and Geophysics, Canberra, p. 3-20. (IAHS Pub1ication No.131.)

Kurowski, L. 1891. Die Hohe der Schneegrenze. Geographische Abhandlungen, Bd. 5, p. 119-60.

LaChapelle, E.R. 1962. Assessing glacier mass budgets by reconnaissance aerial photography. Journal of Glaciology, Vol . 4, No. 33, p. 290-97.

LaChapelle, E.R. 1965. The mass budget of Blue Glacier, Washington. Journal of Glaciology, Vol. 5, No. 41, p. 609-23.

Meier, M.F. 1961. Mass budget of South Cascade Glacier, 1957-60. U.S. Geological Survey. Professional Paper 424-B, p. 206-11.

Meier, M.F. 1965. Glaciers and climate. (In Wright, H.E., jr, and Frey, D.G., ed. The quaternary of the United States. Princeton, Princeton University Press, p. 795-805.)

Meier, M.F., and Post, A.S. 1962. Recent variations in mass net budgets of glaciers in western North America. Union Géodésique et Géophysique 
Internationale. Association Internationale d'Hydrologie Scientifique. Commission des Neiges et des Glaces. Colloque d'obergurgl, 10-9-18-9 1962, p. 63-77. (Publication No. 58 de 1 'Association Internationale d'Hydrologie Scientifique.)

Meier, M.F., and Tangborn, W.V. 1965. Net budget and flow of South Cascade Glacier, Washington. Journal of Glaciology, Vol. 5, No. 41, p. 547-66.

Meier, M.F., and others. 1971. Ice and water balances at selected glaciers in the United States. Combined ice and water balances of Gulkana and Wolverine Glaciers, Alaska, and South Cascade Glacier, Washington, 1965 and 1966 hydrologic years, by M.F. Meier, W.V. Tangborn, L.R. Mayo, and A.[S.] Post. U.S. Geological Survey. Professional paper 715-A.

Meierding, T.C. 1982. Late Pleistocene glacial equilibrium-line altitudes in the Colorado Front Range: a comparison of methods. Quaternary Research, Vol.18, No. 3 , p. 289-310

Mercer, J.H. 1961[a]. The estimation of the regimen and former firn limit of a glacier. Journal of Glaciology, Vol. 3, No. 30, p. 1053-62.

Mercer, J.H. 1961[b]. The response of fjord glaciers to changes in the firn limit. Journal of Glaciology, Vol. 3, No. 29, p. 850-58.

Miller, G.H. 1973. Late Quaternary glacial and climate history of northern Cumberland Peninsula, Baffin Island, N.W.T., Canada. Quaternary Research, Vol. 3, No. 4 , p. 561-83.

Miller, G.H. Unpublished. Glacial and climatic history of northern Cumberland Peninsula, Baffin Island, Canada, during the last 10,000 years. [Ph.D. thesis, University of Colorado, Boulder, 1975.]

Müller, F. 1977. Fluctuations of glaciers, 1970-1977. (Vol. III.) A contribution to the International Hydrological Programme. Compiled for the Permanent Service on the Fluctuations of Glaciers of the IUGGFAGS/ICSU. Paris, International Commission on Snow and Ice of the International Association of Hydrological Sciences and UNESCO.

Nielsen, L.E. 1957. Preliminary study on the regimen and movement of the Taku Glacier, Alaska. Bulletin of the Geological Society of America, Vol. 68, No. 2, p. 171-80.
Nye, J.F. 1965. A numerical method of inferring the budget history of a glacier from its advance and retreat. Jownal of Glaciology, Vol. 5, No. 41, p. 589-607.

Oke, T.R. 1978. Boundary layer climates. London, Methuen and Co. Ltd.

Osmaston, H.A. 1975. Models for the estimation of firnlines of present and Pleistocene glaciers. (In Peel, R.F., and others, ed. Processes in physical and human geography: Bristol essays, edited by R.F. Peel, M.D.I. Chisholm, and P. Haggart. London, Heinemann Educational Books Ltd., p. 218-45.)

Paterson, W.S.B. 1981. The physics of glaciers. Second edition. Oxford, etc., Pergamon Press. (Pergamon International Library.)

Porter, S.C. 1970. Quaternary glacial record in Swat Kohistan, West Pakistan. Geological Society of America. Bulletin, Vol. 81, No. 5, p. 1421-46.

Porter, S.C. 1975. Equilibrium-line altitudes of late Quaternary glaciers in the Southern Alps, New Zealand. Quaternary Research, Vol. 5, No. 1, p. 27-47.

Renaud, A. 1952. Observations on the surface movement and ablation of the Gorner Glacier (Switzerland). Jorenal of Glaciology, Vol. 2, No. 11, p. 54-57.

Schytt, V. 1967. A study of ablation gradient. Geo grafiska Annaler, Vol. 49A, Nos. 2-4, p. 327-32.

Shumskiy, P.A. 1946. Energiya oledeneniya $i$ ahizn' lednikov [The energy of glaciation and the life of glaciers]. Moscow, Ogiz. Gosudarstvennoye Izdatel'stvo Geograficheskoy Literatury. [English translation: U.S. Snow, Ice and Permafrost Research Establishment. Translation 7, 1950.]

Smith, I.N., and Budd, W.F. [1981.] The derivation of past climate changes from observed changes of glaciers. [Union Géodésique et Géophysique Internationale. Association Internationale des Sciences Hydrologiques. ] Sea level, ice, and climatic change. Proceedings of the symposium held 7-8 December 1979 droing the 17th general assembly of the International Union of Geodesy and Geophysics, Canberra, p. 31-52. (IAHS Publication No. 131.)

Sugden, D.E., and John, B.S. 1976. Glaciers and Landscape: a geomorphological approach. London, Edward Arnold. 